\title{
HANNE VEBER
}

\section{SAMLING, SAMLERE OG JÆGER-SAMLERE}

\section{Primitiv erhvervskultur og civilisationens fix}

\begin{abstract}
„At samle“ handler ifølge James Clifford om at tage verden i besiddelse, skabe sig en plads i den. (Clifford 1988:218). Clifford taler om at samle på ting og om den samling af det eksotiske, det kuriøse og det sjældne, som museer, filatelister og kunstelskere hen-giver sig til. Men sammenlignende studier af forskellige typer af sådanne samler-jægere, som samler eller indhøster naturens eller omgivelsernes frugter og for hvem indsamling er led i en subsistensstrategi, viser, at også denne art samling i høj grad handler om at skabe et rum for en form for væren, der definerer en særlig identitet. Der er i alle tilfælde tale om, at det som sættes i spil er tiden og det sociale. Det gøres på forskellige måder og rettet mod meget forskellige interesser. For samleren af kuriosa, kunst, frimærker og lignende handler det om at samle sammen, samle til huse, samle på noget, eller med Cliffords ord, „,samle en verden omkring sig selv“ (op.cit.:229). For samler-jægeren handler det i første omgang om at skaffe sig et udkomme. Men ser vi nøjere efter, handler det for sidstnævnte lige så meget om at undgå at samle på noget, mere specifikt, undgå at op-hobe materiel ejendom og, vigtigst, undgå de sociale bindinger, som medieres af ting og af udvekslinger, som indebærer fastlagte relationer, der strækker sig gennem længere tidsforløb.
\end{abstract}

Samlere synes i en vis forstand at være optaget af fors $\emptyset \mathrm{g}$ på at sætte sig uden for tiden. Samlerne af kunst, Barbiedukker, veteranbiler og andet skaber deres egen eksklusive verden uden for hverdagens trivielle rum og tidsskemaer. Hvor samlingen omfatter gamle ting, fastfryses det udsnit af fortiden, tingen repræsenterer, i et idealiseret fantasme, der gør det muligt at ,glemme“ tiden, virkelighedens tid, med dens processer af ufærdig skabelse og forfald, avl, travlhed, slid og møje, gentagne cykler af udvikling og afvikling, meget betegnende også forstået som ,tidens tand“. Denne ambivalente fastfrysning af tiden i en selektiv samling af og hægen om særlige ting er især tydelig i samlinger, der handler om personer og familier i form af billeder, fotos, og personlige genstande, minder (Otto \& Pedersen 1998). En radikalt anderledes måde at forholde sig til tiden på ses i de typer af samfund, som længe var antropologiens sine qua non, verdens jæger-samlere, for hvem indsamling var og er en måde at tilvejebringe føde på.

Jæger-samler-forskningen beror selv på en særlig form for indsamling, nemlig på samling af viden om jæger-samlere. Jeg skal i det følgende kort redegøre for nogle af de pointer, jæger-samler-forskningen har fundet frem til, og jeg skal præsentere et 
erhvervsform betegnedes i ældre etnografi som „omstrejfen“, og de små grupper kaldtes „horder“. De sås at leve fra hånden og i munden, en karrig og lidet misundelsesværdig tilværelse.

Jæger-samlere findes, hvor jorden er uegnet til dyrkning af afgrøder og hvor der ikke heller findes mulighed for husdyrhold. De er henviste til at fouragere for at finde føde; de overlever, om man så må sige, fra dag til dag. De oplagrer ikke fødemidler og har ikke udviklet den specialiserede arbejdsdeling, der er nødvendig for at opbygge komplekse samfundsinstitutioner med kontinuitet i tid og rum. Deres materielle kultur er simpel. Deres ceremonielle og sociale liv kan derimod være højt udviklet og yderst kompliceret (op.cit.:12-20). Dette sidste fremhævede Nicolaisen hyppigt, ligesom sine fagfæller i midten af det 20. århundrede, som med flid gjorde opmærksom på, at primitiv kultur og civilisation ikke kan stilles op som to adskilte fænomener af den simple grund, som Nicolaisen formulerede det, at selv den højst udviklede form for civilisation ikke alene har sin rod i primitive kulturtilstande, den har stadig træk til fælles med de primitive kulturer (op.cit.:12-13). Den sammenhæng mellem jæger-samlere og højt udviklet civilisation, som Nicolaisen ser på dette meget abstrakte plan, hvor det er menneskehedens fælles oprindelse, det handler om, findes i praksis også på det konkrete, historiske plan, hvor sammenhængen er faktuel og definerbar inden for sociopolitiske og $\varnothing$ konomiske parametre. Dette sidste tillagde man imidlertid ringe betydning, så længe man fastholdt det evolutionære perspektiv som den optik, jæger-samlerne blev set gennem.

Jæger-samlerne har imidlertid ikke fået lov at beholde rollen som repræsentant for det arkaiske menneskelige minimalsamfund, som det blev konciperet i europæisk evolutionstænkning. Sidst i 1950'erne blev jæger-samlerne nemlig genstand for en ny feltarbejdsbaseret antropologisk interesse, der blandt andet ville undersøge det empiriske belæg for de forestillinger, man indtil da havde gjort sig om jæger-samler-samfundene. Det førte gennem 1960'erne og de følgende årtier til en serie specialiserede konferencer, der samlede jæger-samler-forskere fra flere verdensdele og fra fagdiscipliner, der inkluderer både antropologi, arkæologi, psykologi og primatologi. Til at begynde med var teoretiske diskussioner om band-organisering og kulturøkologi i centrum. Den systematiske jæger-samler-forskning ville udvikle nogle fælles perspektiver, der kunne muliggøre sammenligning og generalisering. Den megen ny information, der blev samlet og behandlet, føjede nye og mere nuancerede dimensioner til jæger-samler etnografien. Forskningen forgrenede sig siden i forskellige retninger og affødte efterhånden et væld af specialiserede publikationer. Det er ikke stedet her at gå i detaljer. Blot skal enkelte hovedtræk fremhæves, al den stund her faktisk var tale om flere små revolutioner i tænkningen ikke blot om konkrete jæger-samlere, men i bredere forstand om de elementære former for socialt samliv, herunder de to køns roller i artens forsørgelse, og om menneskelige fællesskabers indretning. Her var fokus især på det fællesskab, som medieres gennem udveksling af materielle goder, og på de ambivalente forhold mellem jæger-samlere og andre omgivende eller tilgrænsende samfund, hyppigt karakteriseret ved forskellige varianter af dominans- og underordningbestræbelser fra sidstnævntes side. Endelig førte den ny forskning til overvejelser over selve konceptualiseringen af jæger-samlere som kultur- og livsform.

Grundlæggende blev det til en begyndelse klart, at man måtte revidere det tidligere syn på forholdet mellem de to køns produktive bidrag til livets opretholdelse. Forskningen viste nemlig, at i jæger-samler-samfund ,fylder“ indsamlingen, set fra et ernærings- 
eksempel på indsamling og dens betydning i et indiansk samfund i Amazonas. Jeg skal også forbinde nogle af de indsigter, der kan hentes i jæger-samler-forskningen og i mit eget eksempel, med fors $\varnothing \mathrm{g}$ på tværkulturelle læsninger af nogle af de karakteristika, der knyttes til indsamling, samling og jæger-samlere, og som viser sig at have mere generel anvend-barhed med hensyn til at forstå det samspil mellem iscenesættelsen af tid og forvaltningen af sociale relationer, som aftegner menneskers og gruppers identiteter $\mathrm{i}-\mathrm{og}$ måske især i - det moderne eller postmoderne samfund.

\section{Jæger-samler-forskningen}

Antropologien opererer med begrebet jager-samlere som betegnelse for en kultur- og erhvervsform baseret på jagt kombineret med indsamling af de spiselige dele af vilde planter, insekter og forskellige smådyr. Jæger-samlere er folk, som vi i vor barndom kendte som pygmæer og australske indfødte, hottentotter og buskmænd i Kalahariørkenen, men de er også forrige århundredes paiute i Nevadas ørken, sirionoindianerne i det $\varnothing$ stlige Bolivia og nutidens huaorani i det vestlige Amazonas og mange, mange flere. Fælles for dem er, at de lever af de dyr og de frugter, naturen kaster af sig. Afdøde professor i etnografi Johannes Nicolaisen talte om „samlere og lavere jægere“, en kategori, han havde fra sin forgænger i faget, kulturgeografen Gudmund Hatt. Han sagde herom: „Vi anser denne erhvervsform for den ældst kendte, og det er betegnende, at folk, som hører herhen, fortrinsvis bebor de mest afsides liggende egne af kloden" (Nicolaisen 1963:14). Når jægerne hos jæger-samlerne betegnedes som ,lavere“, var det for at skelne dem fra de „højere jægere“, som, med Nicolaisens ord, var „karakteriseret ved, at samler-erhvervet er gået tilbage, mens til gengæld jagtens betydning er vokset ved specialisering med hensyn til enkelte, talrigt forekommende dyrearter" (op.cit.:20). De klassiske eksempler på „højere jægere“ er folk som eskimoerne og prærieindianerne i Nordamerika. Ud over den ringe specialisering er det, som gør ,lavere jægere“ lave, altså indsamlingen, en aktivitet der især optager kvindernes arbejdskraft. Etnografiens fædre fik hermed indsamling-og-jagt til at falde på plads som en arkaisk, uudviklet erhvervsform i et verdensbillede, der var stærkt farvet af evolutionistiske tanker om arternes og kulturformernes udvikling. Hermed kunne man se jæger-samlere, som i nutiden var at finde i marginal-områder, som en art „levn“ fra menneskets fortid, fra palæolitikum, det vil sige fra før agerbrugets og kvægavlens oprindelse. Viden om det arkaiske samfund kunne altså hentes gennem studier af nulevende jæger-samler-folk, og det er ud fra studier af dem, man har identificeret nogle generelle træk ved jæger-samler-samfund som samfundstype.

Sociopolitisk karakteriseres de små og spredte befolkninger, her er tale om, som band-samfund, demografisk set små grupper på i snit 25 og højst 50 personer, oftest ledet af én mand, en primus inter pares, som leder i kraft af sine personlige talenter og den tillid, gruppen har til hans formåen. Den sociale organisation baseres på slægtskab. Statusforskelle ud over dem, der vedrører alder og køn, findes ikke. Arbejdsdelingen begrænses til en deling efter køn, oftest således at mænd primært jager og fisker, mens kvin-derne samler. Der forekommer dog overlapninger til begge sider. Det er grupper med en egalitær indstilling og en høj grad af mobilitet og fleksibilitet, således at man kan flytte sig hurtigt alt efter føderessourcernes forekomst og skift i vejrlig og personkonstellationer. Befolkningstætheden er lav, ofte under én person pr. $\mathrm{km}^{2}$. Denne mobile 
ducenten selv ingen kontrol har over, hvem der får del i produkterne (Woodburn 1988). Den første form kendes i et meget begrænset antal tilfælde og repræsenterer det mest simple økonomiske system, etnografien har beskrevet (Burch, Jr. \& Ellanna 1994:5). „Forsinket afkast“" synes derimod at karakterisere de fleste kendte samler-jæger-samfund såvel som en uendelig række tribale og agrare former for ikke-industrialiserede samfund. I $\varnothing$ konomiske systemer karakteriseret ved „,forsinket afkast“ forudsætter produktionen som regel en mere omfattende investering i form af for eksempel fremstilling af fælder, net, både eller andre produktionsmidler, som giver et afkast over lang tid, eller der kan være tale om oplagring af fødemidler under forskellige former. Under alle omstændigheder modsvares disse investeringer af teknologi og arbejde næsten altid af eksklusive krav på kontrol over bestemte produkter, viden, eller andre personers (for eksempel kvinders) arbejdskraft $^{1}$ (Woodburn 1998). Disse krav overskrider både det umiddelbare afkast og den sociale lighedsideologi, der synes at følge i kølvandet på den simple økonomiske orden. For evolutionistisk tænkende forskere indebærer dette, at den strukturelle ulighed, hvis opkomst man ellers havde tilskrevet de agrare samfund, kan genfindes i mere eller mindre rudimentære former i både tribale og band-organiserede samfund (Hann 1998:11). De ,simple“ band-samfund havde altså vist sig ikke at være helt så simple og homogene, som man havde vænnet sig til at tro.

Samtidig kunne man konstatere, at samler-jæger-samfund med ,umiddelbart afkast“ som fremherskende norm næsten altid er at finde som enklaver omgivet af landbrugseller hyrdefolk, til hvem de står i et dominans-underordnings-forhold mens det samme ikke er tilfældet med samler-jæger-samfund med „forsinket afkast“. Nærmere empiriske studier gjorde det herefter muligt at begynde at se den fleksibilitet og tendens til fission, som er karakteristisk for systemer med ,umiddelbart afkast“" som en strategi til undvigelse eller afbødning af dominansforhold (Bender \& Morris 1988:12). Dermed blev det også muligt at begynde at se denne type samler-jæger-samfund som en kultur- eller livsform, der er tilpasset et varigt samspil med andre typer samfund i en art symbiose, potentielt konfliktfuld men samtidig et samspil hvoraf begge parter drager fordel.

Med hensyn til den type $\varnothing$ konomisk orden, der karakteriseres ved ,umiddelbart afkast“ - den mest simple form - har James Woodburn siden foreslået ordet ,deling“ (sharing) som en mere dækkende betegnelse. Begrebet ,umiddelbart afkast“" indebærer en formodning om ejerskab eller besiddelsesret, som der ikke er empirisk belæg for i samler-jæger konteksten. Ordet ,deling“ giver en mere præcis henvisning til det som foregår i band-samfund med et udstrakt fællesskab og en udbredt alle-deler-alt-med-alle-norm. Denne form for deling ser Woodburn som den mest universelle form for $\emptyset$ konomisk adfærd blandt mennesker, forskellig fra og mere fundamental end reciprocitet (1998:50). Antropologien (efter Lévi-Strauss) har vænnet os til at se reciprocitet som selve grundlaget for kultur og samfund. Reciprocitet indebærer imidlertid, siger Woodburn, at noget ydes mod forventet gengæld. Reciprocitet deler op i givere og modtagere, og formålet med udvekslingen ses som etablering af bånd mellem adskilte enkeltstående individer. Når Woodburn derimod taler om „,deling“, er der ikke i udgangspunktet nogen bånd, som skal bindes. Det økonomiske fællesskab eksisterer nemlig forud for udvekslingens transaktioner. Dette udelukker ikke, at der i disse samfund samtidig praktiseres særlige former for bortgiven af føde eller materielle ting, som skaber bånd mellem bestemte personer (ibid.). Modsat vante forestillinger er reciprocitet blot ikke den primære eller grundlæggende $\emptyset$ konomiske ordning i samler-jæger-samfund. ${ }^{2}$ 
mæssigt synspunkt, mere i billedet end jagten og dens produkter. Indsamlingen bidrager sine steder med helt op til tre fjerdedele af gruppens energibehov (Burch, Jr. \& Ellanna 1994:11). Betydningen af arbejdsdelingen mellem mænd og kvinder måtte hermed tænkes om. Mændenes jagt kunne ikke længere ses som det bærende og altafgørende element i denne erhvervsform - uagtet jægerne måske selv insisterede på, at det var sådan, det forholdt sig. Hermed brød man radikalt med ældre tiders forståelse af kønsforhold i jæger-samler-samfundene. Artikelsamlingen fra den epokegørende jæger-konference (i Chicago 1966), som udkom i 1968 under titlen Man the Hunter (Lee \& DeVore 1968), blev i 1981 efterfulgt af modstykket Woman the Gatherer (Dahlberg 1981), som signa-lerede den ny opprioritering af kvindernes indsamling. Jæger-samlere blev til samlerjægere, hvor ordenes rækkefølge skulle afspejle den afgørende prioritering. Et andet væsentligt tema, som fortsat diskuteres, er arten af udveksling såvel inden for samler-jæger-samfundet som mellem det og de omgivende samfund (landbrugs-, industrisamfund eller andet). Som vi siden skal se, kan formen for udveksling give os væsentlige fingerpeg om hvordan, under hvilke omstændigheder og med hvilke langtidsvirkninger grupper af samler-jægere fungerer i samspil med andre og mere komplekse samfundssystemer.

\section{At dele alt med alle - „gaven“ vendt på hovedet}

Forståelsen af samler-jægerne var i første omgang konciperet omkring en art enheds-model, hvor indsamling-og-jagt som erhvervsform knyttedes til specifikke sociopolitiske træk såsom ,band“"-organisering, det vil sige en fleksibel og relativt simpel social organisation, svagt lederskab, kollektiv brugs- eller ejendomsret til ressourcerne og ringe grad af social ulighed. Disse træk syntes at høre til samler-jæger-samfund som del af den „,pakkeløsning“, modellen rummede. Enhedsmodellen gav imidlertid problemer med at forklare, at mange samler-jæger-samfund faktisk afviger fra modellen. Det gælder for eksempel med hensyn til stærk social differentiering (nordvestkystindianerne), eksklusiv ejendomsret til eller råderet over ressourcer (cree-jægere i Canadas østlige skovland) eller kompleks social organisation (de australske flersektionssystemer), der således forekommer i samler-jæger-samfund, som i alle andre henseender er ganske simple - i overensstemmelse med modellen. Fors $\emptyset$ g på at forklare ,,afvigelserne“ som resultater af særligt rige lokale ressourcer eller kontakt med fremmede samfund holdt ikke (Bender \& Morris 1988). Der skulle flere radikale omtænkninger til, før mere fremkommelige begrebssæt til forståelse af samler-jæger-samfundenes varierede sociale organisation af-tegnede sig.

En af indfaldsvinklerne til dekonstruktion af enhedsmodellens forsimplede idé om samler-jægernes sociale system blev spørgsmålet om, hvad der sker med jagtens og indsamlingens produkter, det vil sige, hvem der konsumerer hvad hvornår. På basis af stu-dier blandt afrikanske samler-jægere formulerede James Woodburn nogle begreber til skelnen mellem to former, nemlig et såkaldt „forsinket afkast“ (delayed return) og et ,umiddelbart afkast“ (immediate return), som er de to grundformer, man finder i samler-jæger-samfund. I sidste tilfælde disponerer individerne selv umiddelbart over resultatet af deres arbejdsindsats og får glæde af den her og nu, mens det i første tilfælde gælder, at produkterne af en persons arbejde er underlagt nogle sociale regler for fordeling, således at de tilflyder mange andre end producenten, ofte på en sådan måde, at pro- 
ning nu peger på, er, at i samfund, hvor kræve-deling er den gældende norm, passer denne Mauss'ske idé om at gaver gives ikke med måden, hvorpå udvekslingen faktisk foregår. At tale om en pligt til at modtage, som Mauss gør det, er i disse samfund ganske absurd. Thi i samfund med „kræve-deling“ kommer kravet altid før ydelsen. At tilbyde en „gave“ i Mauss'sk forstand falder her uden for enhver kontekst og vil sandsynligvis blive opfattet som et tegn på undergivenhed, dumhed eller tilløb til lusk (Peterson 1993). ${ }^{3}$

En anden omtænkning af jæger-samlerne skyldtes en misforståelse, som imidlertid skulle vise sig at få vidtrækkende konsekvenser både i jæger-samler-forskningen og i antropologien generelt.

\section{„Det oprindelige overflodssamfund“?}

I forbindelse med „Man the Hunter“ konferencen i 1966, som af mange opfattes som grundlæggende for den moderne samler-jæger-forskning, var Marshall Sahlins inviteret til at diskutere oplæggene. Sahlins, der ikke selv havde arbejdet med samler-jægere, præsenterede en idé, han havde udkastet på grundlag af nogle spredte udsagn, han havde fundet i litteraturen, nærmere bestemt i rejsebeskrivelser og i tre feltstudier blandt buskmænd og australske indfødte. På det grundlag mente han at kunne konkludere, at tilvejebringelsen af føde i samler-jæger-samfund kan klares ved så lidt som 3-5 timers arbejde om dagen eller mindre i grupper, som lever i de mest frugtbare egne. Dette - altså den udstrakte „fritid“, som måtte formodes at fylde resten af samler-jægernes døgn fik Marshall Sahlins til at udnævne samler-jægerne til „oprindelige overflodssamfund” (Sahlins 1974), en betegnelse, som henviser til ikke blot en rigelighed af „fri“ tid til at fornøje sig, men til en frihed fra tvangen til evig arbejdsflid, en frihed baseret på tillid til, at naturens ressourcer altid vil være tilgængelige i tilstrækkelig mængde, og at man derfor ikke behøver at bekymre sig om i morgen eller dagen derpå, at man altid kan tage den med ro, kan nyde livet og aldrig behøver at have travlt og skynde sig (op.cit.:29). Sahlins' provokerende nytænkning af samler-jægerne antydede, at man kan være rig uden at eje noget som helst; at fattigdom med andre ord er en social status, en opfindelse, som civilisationen fører med sig (op.cit.:37).

Idéen om „overflod“ i samler-jæger-samfundene skulle dog ved nærmere eftersyn vise sig ikke altid at holde - i hvert fald i det omfang man ville forstå „overflod“ som rigelighed af føde og andre fornødenheder til livets opretholdelse og behag. Blandt de ny tilgange til samler-jægere var tidsstudier kommet til som del af det kulturøkologiske analyseperspektiv, der blomstrede op fra 1960'erne og frem. Gennem tidsstudier kunne man måle effektiviteten i arbejdsgange og forskellige former for teknologi i forhold til udbyttet af en given arbejdsindsats, og man kunne måle arbejdsindsatsens intensivitet og det relative tidsforbrug på de enkelte arbejdsopgaver i forhold til hinanden. De nye studier gjorde det klart, at „overfloden“ i en lang række samler-jæger-samfund er ganske tvivlsom eller kun tilsyneladende. Hvor der er overflod, er det en overflod af tid snarere end en overflod af fødemidler og andre goder. Ressourcerne kan være så spredte og forekomsten så begrænset, at fremskaffelsen af føde optager al disponibel tid. Sæsonvariationer kan visse steder forekomme med så store udsving, at veritable hungerperioder er et regelmæssigt tilbagevendende problem (Yesner 1994; Shnirelman 1994). Det er med andre ord ikke altid forbundet med idel lykke og frihed at leve som samler-jæger. 
Ideen om reciprocitet som den elementære og mest simple form for udveksling i tribale samfund var blevet knæsat af Marshall Sahlins i 1960'erne, idet han skelnede mellem reciprocitet og redistribution. Hos Sahlins, der havde hentet begreberne hos Elman R. Service (som arbejdede med jægerfolk og evolution), sås reciprocitet som den oprinde-lige og elementære udvekslingsform blandt mennesker. Reciprociteten kunne være ,generaliseret“, ,negativ“ eller ,simpel“, men den rummede altid en forventning om gen-sidighed. Det gælder også den ,generaliserede reciprocitet“, som indebærer, at gengæld, man skylder for en ydelse man har modtaget, kan udsættes på praktisk talt ubestemt tid; forventningen om gengæld ligger dog stadig tilbage som en moralsk norm, eventuelt som en pligt til taknemmelighed (Sahlins 1968:82-3). Redistribution derimod forudsætter hos Sahlins en central fordelingsinstans, som produkter tilflyder for efterfølgende at blive uddelt efter de regler, der måtte gælde i det pågældende samfund. Redistribution er her „høvdingeskab økonomisk set“ (op.cit.:94-5).

Woodburn finder nu, at der ved dannelsen af forestillingen om reciprocitet og redistribution er sket en fejllæsning af empirien. I simple samler-jæger-samfund, hvor man deler alt, siger han, er der ingen forventninger om, at ydelser før eller siden skal eller vil blive gengældt. Reciprocitet i udvekslingen er altså præcis $i k k e$, hvad det drejer sig om. Der er snarere tale om en umiddelbar redistribution forstået som en primitiv velfærds-ideologi, hvor alle har krav på del i de goder, der måtte findes i samfundet. Det er dog ikke en art ,primitiv kommunisme“, der er på spil. Thi folk har klare begreber om individuel ejendomsret; de sociale normer tillader blot ikke ophobning af ejendom ud over, hvad man aktuelt kan konsumere eller har brug for (Woodburn 1998).

Hvad der er allermest interessant, er måske, at fordelingen typisk foregår som det, der er blevet kaldt „kræve-deling“ (demand sharing) (Peterson 1993). Det virker på den måde, at alle i princippet har ret til at modtage; alle har altså krav på at få del i de goder, som findes. Denne ret til og krav på en del af en hvilken som helst „,kage“, der måtte være tilgængelig, ses som en naturlig ret som følger med det at være medlem af samfundet eller gruppen, hvordan denne end måtte være defineret. Den, som besidder en „kage“, er forpligtet til at give til den, som stiller krav om del i den. Førstnævnte har altså en pligt til at give, hvor den anden har en ret til at modtage. Denne ret til at modtage ledsages $i k k e$ af en pligt til at give igen. Her er altså tale om en norm for deling, som er fuldstændig modsat af påstanden om gavegivningens universelle princip, som det fremstilles hos Marcel Mauss i hans klassiske bog om „Gaven“ og ,gaveudvekslingens form og logik i arkaiske samfund“, som undertitlen lyder i den nylige danske oversættelse af bogen (Mauss 2000), som udkom på fransk i 1923-24. Hos Mauss bygger den samfundsmæssige udveksling på et gavegivningsprincip, ifølge hvilket gaver forpligter den, til hvem den gives, til både at modtage den med tak og yde en anden gave til gengæld på passende senere tidspunkt. Gaver gives i princippet frivilligt, spontant og af gavmildhed. Det udelukker hverken, at giveren i praksis kan have bagtanker med sin gavegivning, eller at modtageren på sin side kan have luret ham. Pointen er, at den gensidige forpligten sig på hinanden, som gaven og modgaven etablerer, skaber et socialt bånd, som i sig omfatter alle de tråde, den sociale sammenhæng er vævet af. „Gaven“ betegner altså ikke „,bare“ en $\emptyset$ konomisk transaktion, men er et totalt socialt faenomen, som på én gang rummer religiøse, moralske, retslige og økonomiske aspekter (Mauss 1980). Denne tænkning omkring ,gaven“ som universelt princip i skabelsen af det sociale har været besnærende og har nydt udbredt accept i antropologien. Problemet, som den ny samler-jæger-forsk- 
samfund, kunne man tilføje. Hermed havde Sahlins, som Bird-David senere påpegede, udstukket en analysemåde, hvorved omverdensforståelse og økonomisk adfærd kunne tænkes sammen i en ny form for kulturantropologisk tilgang til undersøgelse af subsistensformer og socioøkonomisk tilpasning (Bird-David 1992). Dette var også grunden til at Sahlins” begreb om „det oprindelige overflodssamfund“ efterfølgende kom til at leve sit eget liv i antropologien længe efter at det empiriske belæg for den havde vist sig at forsvinde som vand mellem fingrene (ibid.).

Men omtænkningen af jæger-samlerne havde i grunden været indledt allerede i 1950'erne. I forbindelse med udforskningen af Amazonas's indfødte befolkninger havde såvel etnografen Lévi-Strauss som arkæologen Donald Lathrap fra hver deres synsvinkel foreslået, at flertallet af de indianske samfund i Amazonlavlandet historisk reflekterede tilpasninger til progressiv marginalisering, hvad enten de var havedyrkere, jæger-samlere eller kombinerede disse subsistensformer. De burde med andre ord kunne ses som resultater af samfundsmæssig devolution snarere end som repræsentanter for tidlige, for-tidige, kulturformer (Lévi-Strauss 1963 [1952]; Lathrap 1968). Indsigterne fra den efterfølgende og mere systematiske samler-jæger-forskning gav anledning til videre overvejelser over hvorvidt ikke blot usikkerheden med hensyn til overlevelsesmuligheder men også den sociale organisering i mange, men ikke nødvendigvis alle, samler-jæger-samfund hænger sammen med en social og geografisk marginalisering eller ,indkapsling“ i omgivende økonomiske systemer (Woodburn 1988). Når de konventionelle jæger-samler-studier ikke havde været opmærksomme på dette forhold, hang det muligvis sammen med, at en marginalisering eller , indkapsling“ af samler-jægerne meget vel kunne have gået for sig gennem meget lange tidsrum, således at den tilpasning, der var sket, var kommet til at tage sig ud som „,naturlig“. Spørgsmålet kom derfor ikke for alvor under debat, før forholdet mellem samler-jæger befolkninger og de stater, de hører under, af andre grunde kom i fokus.

\section{Arkaiske „vilde“ og postmoderne hybrider}

Gennem det 20. århundredes senere tiår var det kommet til at stå forskerne klart, at jæger-samlerne, i deres oprindelige (formodede) ,vilde og rå tilstand“, stille og roligt var ved at forsvinde. ${ }^{4}$ Man begyndte i den forbindelse at se på menneskerettigheder, lovgivning, territoriale tilhørsforhold, ejendoms- og brugsret til landområder, regeringsindgreb af forskellig art og stigmatiseringens implikationer.

Interessen for territorialitet har altid været vigtig i studiet af jæger-samlere: et overblik over, hvem der bor hvor, hvornår, hvor længe, hvor mange og hvorfor, er helt grundlæggende for at kunne sige noget om disse samfund. Det kræver kortlægning af områder, demografiske data, viden om årscyklus og naturressourcernes sæsonvariationer og meget andet, som hører til det etnografiske feltarbejdes klassiske håndværk (se for eksempel Steward 1977). Indsamlingen af disse typer viden er i teorien ligetil, men tidskrævende og besværlig i praksis. Nu gav aktuelle omstændigheder anledning til fornyede indsatser på feltet. Den øgede interesse for territorialitet gennem sidste halvdel af det 20. århundrede var hyppigt knyttet til retstvister om indfødte folks jordkrav, som førtes for domstolene i Australien, Canada og USA og siden også i Latinamerika, Afrika og Asien. ${ }^{5}$ Her blev antropologer involveret som ekspertvidner for både anklager og forsvar. I alle 
Ydermere er det sådan, som Bird-David har vist (1992), at de eksempler, Sahlins havde brugt som belæg for sin påstand om de ,oprindelige overflodssamfund“, slet ikke, når det kom til stykket, var studier af fuldtids samler-jægere. De kunne derfor ikke bruges til at belyse samler-jæger-samfunds reproduktion som sådan. Buskmændene (Dobe !Kung), som han havde hentet fra Lees tidlige studier (Lee 1968, 1969), viste sig at have været involveret i lønarbejde ligesom de også i perioder dyrkede afgrøder til eget forbrug (Lee 1976, 1979). Deres eksempel kunne derfor næppe bruges til at sige ret meget om betingelserne for et samler-jæger-samfunds reproduktion over tid, eller om deres eventuelle overflod eller mangel på samme - hvis man ved samler-jægere forstod folk, hvis næringsvej ene og alene var indsamling og jagt. Det samme gjaldt Sahlins' australske eksempler, som hidrørte fra en ekspedition foretaget af en antropolog og en ernæringsekspert i Arnhem Land i 1948. I to studier havde de målt arbejdsindsatsen hos voksne indfødte og fundet ud af, at disse i snit arbejdede 3,6 timer om dagen eller 25,2 timer om ugen (7 dage) og producerede føde svarende til et indtag på i snit 2,130-2,160 kalorier om dagen, det vil sige fuldt tilstrækkeligt til at opretholde livet (Sahlins 1974:18). Sahlins havde ret, for så vidt som han påpegede, at evolutionstænkningens billede af jæger-samlere som stakler, der frister en kummerlig tilværelse, ikke holdt. Der betød imidlertid ikke, at idéen om en oprindelig overflod nødvendigvis var rigtig.

Kritikken rettedes, ikke overraskende, mod Sahlins' idyllisering af samler-jægerlivet og herunder generelt mod forestillingen om, at man kan forstå samler-jæger-samfund isoleret som autonome kultur- og produktionsformer. I det ene af de australske eksempler, Sahlins havde brugt som belæg for sit „oprindelige overflodssamfund', havde man for eksempel studeret ni voksne personer, 6 mænd og 3 kvinder, som man havde fundet på en missionsstation og overtalt til at medvirke i et praktisk jagt-og-indsamlings-eksperiment. To af mændene i gruppen blev imidlertid allerede på fors øgets anden dag så trætte af den kost, eksperimentet kastede af sig og som fortrinsvis bestod af animalsk føde, at de gik hjem efter noget mel og ris (Bird-David 1992:26). Ekspeditionslederne lykkedes ganske vist at overtale dem til at gemme lækkerierne til forsøget var afsluttet, men hændelsen giver os en ide om, at disse samler-jægere måske ikke var ganske for-nøjede med samler-jæger-livets kulinariske udbud, fordi de $i$ virkeligheden var vant til noget andet. Samtidig må vi også give Jon Altman, en australsk jæger-samler-forsker, ret når han siger, at den ,overflod“ den lille gruppe var i stand til at producere i løbet af eksperimentets 14 dage, var en overflod med baggrund i finansiel støtte fra den australske velfærdsstat og adgang til købmandsvarer og ny teknologi (Altman 1992:35). Thi fors $\emptyset$ gets ni voksne kunne ikke - heller ikke på det eksperimentelle niveau - siges at repræsentere et oprindeligt samler-jæger-samfund al den stund gruppen hverken omfattede børn eller andre ikke-arbejdsføre personer. Disse var nemlig blevet hjemme (ved missions-stationen), hvor deres forsørgelse var sikret gennem det vi i dag forstår som statslige overførselsindkomster. Skulle fors $\emptyset$ gspersonernes pårørende have været fors $\varnothing$ get gennem det afkast fra jagt og indsamling, som fremkom i fors $\varnothing g$ sperioden, ville der næppe have været noget ,overskud“ at skrive om!

Sahlins' fortjeneste var imidlertid at have set, at samler-jægere ikke fokuserer deres arbejdsindsats på en maksimering af det materielle udbytte men snarere på en tilpasning mellem behov og indsats, der løbende justeres således at begge dele holdes på et realistisk (lavt) blus. Det tillader samtidig at de indretter deres økonomiske adfærd på en tillid til at føde altid er eller vil blive tilgængelig i den omgivende natur - eller i det omgivende 
kommere nu i forskellige former for afhængighedsforhold til omgivende jordbrugs- eller industrisamfund (Christensen \& Aaby 1977:208; se også Burch, Jr. 1994). Nogle af disse marginaliserede og „oprindelige“ folk lever som samler-jægere. Andre kombinerer indsamling og jagt med havebrug og fiskeri og eventuelt med forskellige former for kontraktarbejde eller dyrkning af salgsafgrøder. I mange tilfælde fortsætter jagt, fiskeri og indsamling med at spille en meget vigtig rolle for befolkningernes daglige ernæring.

Som vi har set, er marginalisering ikke det samme som isolation eller autonomi. De fleste af de samler-jæger-samfund, man kender til, har levet og lever i kontakt- og udvekslingsforhold af en eller anden art med andre samfund af mere kompleks type. Disse udvekslingsforhold er ikke altid af ny dato, men rækker ofte langt tilbage i historien. Det er højst bevidstheden om dem hos iagttageren (antropologen/etnografen), som er ny. Her begynder idéen om det simple jæger-samler-samfund som en autonom, selv-produceret størrelse imidlertid for alvor at tage sig ud som en fiktion; jagt-indsamling bundet til en egalitær samfundsform karakteriseret ved mobilitet, tilegnelse af naturens færdige produkter, deling i fællesskab og en idé om overflod fremtræder herefter som både et produkt af og betingelse for den svage gruppes fortsatte inkorporering som enklave i et større og mere komplekst system. Som vi har set, betyder det ikke, at samler-jægere „kun“ findes som historisk marginaliserede grupper, eller at der ikke kendes samler-jæger-folk, som ,altid“ har levet som samler-jægere. ${ }^{6}$ Disse grupper passer bare ikke særlig godt til enhedsmodellens opskrift på jæger-samler-samfundets beskaffenhed.

Den akkumulerede viden om jæger-samlerne og bevidstheden om deres integration i de omgivende samfund har ganske vist undermineret forståelsen af jæger-samlere som selvstændige fænomener, begribelige alene på basis af deres erhvervsform, men den har til gengæld udvidet perspektivet, således at jagt-og-indsamling (eller ,fouragering“ for nu at bruge et lidt mere ,åbent“ udtryk) kan ses som en livsform eller en måde at leve på og forstå verden på, som udmærket kan trives midt i moderne eller postmoderne sammenhænge, hvor jagt-og indsamlingens (,,fourageringens“) økonomi i et globalt perspektiv kun spiller en meget lille og underordnet rolle - uagtet den i visse lokale sammenhænge betyder forskellen mellem overlevelse og udsultning. Hvis moderne jæger-samlerne således i udgangspunktet må ses som marginale i forhold til centre, som de er underordnede, afhængige af eller blot sameksisterer med i et eller andet udvekslingsforhold, er det samtidig blevet muligt at få øje på, hvordan globaliseringen gennem de seneste tiår har tilføjet endnu et lag af centre med tilhørende periferier, som både forstærker og bryder allerede eksisterende afhængigheds- og marginaliseringsprocesser. Det er blevet muligt at koble hightech-informationssystemer med jagtens og indsamlingens sociale organisering af hverdagslivet i funktionelle samspil, der skaber helt ny betingelser for hybride $\varnothing$ konomiske og kulturelle udfoldelser både her og hisset (Turner 1992; Feit 1991).

For at dæmpe en fortløbende afskalningsproces, som foregår i de moderne samler-jæger-samfund i takt med en intensiveret integration i nationalsamfundet, er man eksempelvis i flere lande, hvor den statslige kontrol er velorganiseret og stærk, begyndt at eksperimentere med egnsudvikling og bistandsprogrammer, der skal støtte betingelserne for jagt og indsamling, således at disse aktiviteter fortsat kan udgøre levedygtige livsformer i marginalområderne, hvis de praktiseres efter moderne, videnskabeligt anerkendte principper og i kontrolleret omfang, således at rovdrift på naturen og udryddelse af arterne undgås (Feit 1991; Hitchcock 1993 ). Derved håber man både at hindre, at 
tilfælde førte det til en voldsom intensivering af forskningen, som også afspejledes i de videnskabelig debatter uden for domstolenes regi (Clifford 1988; Maybury-Lewis 1997; Hitchcock \& Biesele 2000).

Gennem arbejdet med disse spørgsmål - og ikke mindst gennem den etnohistoriske forskning, som blev udført i den forbindelse - og med fors øget på afklaring af de indfødte befolkningers retsstatus, skete gradvis endnu en omkalfatring af begrebet om samler-jægere. Det kom til at stå mere klart end nogensinde før, at samler-jægere på ingen måde kan ses at repræsentere menneskeartens oprindelige ,rå og primitive“ tilstand, i den forstand at de har overlevet i fred for omverdenen og udviklingen i klodens mest marginale og isolerede egne. Dette havde Lévi-Strauss været inde på allerede i 1950'erne, da han rejste spørgsmålet, om vi overhovedet kan tale om „sande“ jæger-samlere i Sydamerika, og hvis vi kan, kan vi så forklare det som en repræsentation af menneskets oprindelige tilstand? Lévi-Strauss' eget svar var negativt. Han sagde (i 1952):

\begin{abstract}
Visse stammer forekommer i dag meget primitive, [...] Men de, som er helt ukendte med havebrug er sjældne, og de lever alle isoleret blandt grupper på et højere niveau . Disse stammers historie, hvis vi kendte den, ville forklare deres særlige træk bedre end hypotesen om et arkaisk niveau, som de udnævnes til at være levn fra [...] De kan være forhenværende havebrugere, som det er gået tilbage for, efter at ny levevilkår blev dem påtvunget (1963:109-10; min oversættelse).
\end{abstract}

Marginalområder er nemlig ikke bare afsides, men - netop - marginale, det vil sige det er områder, der er karrige og ufrugtbare. Det er også - eller primært - områder, hvis befolkninger er uden politisk indflydelse og marginaliserede i forhold til - men ikke nødvendigvis uden for - de økonomiske ressourcer og netværk, som binder andre befolkningsgrupper og områder sammen (Woodburn 1988). At jæger-samlere lever, eller indtil for nylig levede, afsides og måske primært forsørgede sig ved jagt og indsamling, er altså ikke altid ensbetydende med at de lever eller levede en ,oprindelig“ tilværelse. Det be-tyder, at de fleste jæger-samlere levede og lever som marginalgrupper inden for rammerne af mere komplekse samfund, eventuelt moderne stater. Der er undtagelser fra denne generalisering. Ironisk nok er undtagelserne sådanne samler-jægere, som hører til de mest komplekse blandt samfund, der har indsamling og jagt som primær erhvervsform. Det gælder for eksempel de australske indfødte, som med deres symbolske hierarkier, komplicerede slægtskabssystemer og sindrige regler for social reproduktion vidner om, at samler-jægere, som lever i en verden, hvor alle er samler-jægere, netop $i k k e$ er simple autonome smågrupper, men udvikler omfattende systemer til integrerende kontrol over mennesker, tanker og ressourcer. De passer altså ikke til enhedsmodellens „pakkeløsning“ for jæger-samlere som sociøøkonomisk typologi og er måske derved med til at pege på, at flere af de karakteristika for jæger-samlere, som modellen angiver, er resultater af marginalisering - og ikke omvendt.

I moderne statssamfund konstitueres marginalområder i forhold til det centrum, som kapitalen og staten, deres institutioner og $\varnothing$ konomiske prioriteringer udg $\varnothing$ r. Dette indebærer, at mange af de grupper, vi i dag forstår som „oprindelige folk“, er befolkningsgrupper, som i moderne tid er blevet marginale (Salih 1993). Hvor de for manges vedkommende engang i fortiden udgjorde deres egne centre i komplekse samfund med høvdingedømmer og vidt forgrenede handelsnetværk, som eksempelvis de indianske folk i det postkoloniale Amazonas (se Roosevelt 1993; Taylor 1999), lever deres efter- 
for ashéninkas egen forståelse.

De ser den mest som en art forlystelse - i stil med storbyboeres besøg hos „,døgneren“ eller ,slikmutter“ - om end de også kender til situationer, hvor indsamling i skoven er en nødvendighed for slet og ret at overleve. Men disse situationer ser de som undtagelser fra det „normale“. Det „,normale“ består i denne sammenhæng i at dyrke sin (svedje)have med omhu og hårdt arbejde for derved at skaffe sig og sin familie den nødvendige føde.

Ashéninka lever spredt på bopladser i bjergskoven på Andeskædens lavere liggende udløbere mod øst i et kuperet terræn, hvor nogle af hovedkilderne til Amazonflodsystemet har deres udspring. Området er marginalt i den forstand, at kun en mindre del af jorden er egnet til dyrkning, mængden af dyrevildt er begrænset til smådyr som aber, fugle og mindre gnavere, om end hjorte også ses en gang imellem. På samme måde er bestanden af fisk i floder og vandløb ganske begrænset grundet en i perioder meget voldsom gennemstrømning og en meget svingende vandmængde, som giver dårlige livsbetingelser for de fleste fiskearter. Kombinationen af havebrug, jagt og indsamling (herunder et begrænset fiskeri) gør det imidlertid muligt for ashéninka generelt at holde et pænt ernæringsniveau, om end forsyningen af proteinholdig føde kan være på grænsen til det utilstrækkelige (Denevan 1974). Forholdsvis små udsving i subsistensproduktionen kan derfor hurtigt forrykke balancen, så der opstår fejlernæring. Sådanne udsving kan være forårsaget af kontraktarbejde for mestizerede nybyggere, som afskærer mændene fra at gå på jagt eller begrænser havebrug og indsamling på forskellig vis (Hvalkof 1987:10). Der kan også være uoverensstemmelser blandt ashéninka selv, som tvinger individuelle hushold til at flytte og dermed gør dem delvist subsistensløse i perioden, indtil de har etableret et nyt bosted og en ny have bliver produktiv. I sådanne situationer er muligheden for at overleve på indsamling det „sikkerhedsnet“, ashéninka-familier har til rådighed. Indsamling er imidlertid ikke noget, der kun foregår i krisesituationer, men er en integreret del af dagliglivet på de fleste bopladser.

Ashéninkas produktion er i det væsentlige rettet mod subsistens. Deres basisføde er maniok, yuca, som den betegnes på lokalt spansk, eller kaniri på ashéninka. ${ }^{8}$ Denne rodfrugt dyrkes ved svedjeagerbrug i skoven, hvor mændene står for rydning af et jordstykke og tilplantning af haven, hvorefter kvinderne overtager pasning og høst af afgrøderne. Basiskosten bestående af kogt eller stegt maniok suppleres med små mængder kød fra jagt eller, mere sjældent, fisk fanget i lokale vandløb. Produktion af salgsafgrøder (kaffe og jordnødder) finder kun sted i meget begrænset omfang. Varer, som ashéninka ikke selv fremstiller, skaffes ved byttehandel med andre indianere (ashaninka) eller ved kontraktarbejde for nybyggere. De sidste er mestizer og andine bønder, som er flyttet til gennem sidste halvdel af det 20. århundrede. Kontraktarbejdet består hovedsagelig i rydning af skov og tilplantning af haver med subsistensafgrøder eller kaffe (salgsafgrøde) og marker til græsning af kvæg (salgsafgrøde).

De fleste Pajonal-ashéninka, som lever i skoven, foretager regelmæssigt kortere eller længere indsamlingsekspeditioner ved siden af arbejdet med haverne. Oftest vil indsamlingen ske i grupper af kvinder eller mænd hver for sig. Mændene vil undertiden samle et eller andet ind i forbindelse med en jagttur, enten fordi de tilfældigt træffer på et Ønskværdigt fødeemne, eller fordi de ikke har lyst til at vende tomhændede hjem til bopladsen og kvinderne, som forventer, at mændene skal bringe dem kød eller andet, som regnes for „ordentlig“ mad. Medmindre der råder en situation af absolut fødeknaphed, går mænd sjældent i skoven med indsamling alene for $\emptyset j e$, mens kvinder ofte, visse 
mennesker mister deres eksistensgrundlag og at undgå yderligere social disintegration og affolkning af store territorier, som dermed kommer til at ligge åbne for forskelligartet kriminel eller miljøskadelig aktivitet (krybskytteri). Jagt og indsamling søges med andre ord fastholdt som afhængige supplementer i et økonomisk og politisk system rettet mod helt andre prioriteringer end menneskelig subsistens og velfærd. Vi er hermed kommet meget langt bort fra Gudmund Hatts og andre evolutionstænkeres forestillinger om nutidens jæger-samlere som klodens repræsentanter for en oprindelig, arkaisk, overleven i tidslommer uden for historien. Hvis jæger-samlere lever et liv, der er hårdt, risikabelt og usikkert, skyldes det således andre grunde end dem, evolutionstænkerne lagde i begrebet om de ,lavere“ jægere.

I og med at samler-jægere ikke længere i princippet ses som selvstændige autonome sociale systemer, diskuterer nogle samler-jæger-forskere om man helt bør demontere begrebet ,samler-jægere“. Det sker i en voksende erkendelse af, at nogle af de karakte-ristika, man i jæger-samlerforskningens velmagtsdage mente var udslag af disse samfunds særlige måde at fungere på, måske slet ikke er særegne for samler-jæger-samfund, men faktisk forekommer i alle mulige andre typer af samfund enten som almindeligt udbredte træk eller som lejlighedsvise fænomener (Burch, Jr. 1994; se også Day et al. 1999). Her fungerer de som tilpasningsformer, der næsten altid ved nærmere eftersyn viser sig at have noget at gøre med samspil mellem forskellige typer af samfund eller sociale systemer eller med historiske inkorporationer af simple og tribale samfund i mere komplekse handels- eller dominanssystemer (Feit 1994). Her kan forskningen omkring samler-jægeres samspil med og evne til at undvige inkorporering i andre og mere komplekse systemer muligvis hjælpe til at forstå, hvorledes visse tribale samfund vedblivende lykkes at fastholde forskellige grader af relativ autonomi i forhold til omgivende nationalsamfund.

En mulig tilgang kan bestå i at undersøge, hvad (ind)samling som element i en sub-sistensstrategi i grunden går ud på i et tribalt samfund af den art, som stadig findes i marginale områder. Et eksempel kan hentes i peruansk Amazonas på Andesbjergenes nedre østlige skråninger, ikke mere end en dagsrejse eller to fra Lima, landets hovedstad, men alligevel langt nok væk fra den moderne verden til, at den rejsende kan tro sig flyttet til en helt anden tid og et radikalt fremmed rum. Dette rum tegnes ikke af et samler-jæger-samfund, men af en befolkning af svedjeagerbrugere, for hvem indsamling og jagt spiller en ambivalent, men alligevel meget væsentlig, rolle. Gennem at se nærmere på den form for indsamling, de bedriver, kan vi få et konkret blik på indsamlingens betydning, ernæringsmæssigt og socialt for mennesker, der aktivt praktiserer den, og strukturelt i forholdet mellem dem og det omgivende nationalsamfund. Derefter kan vi vende tilbage til spørgsmålet om hvad fænomenet indsamling tænkeligt betyder på tværs af de meget forskellige empiriske kontekster, hvori det forekommer.

\section{Havedyrkernes Indsamling}

I Gran Pajonal, i et afsides hjørne af den peruanske bjergjungle, lever en indiansk befolkning, ashéninka, ${ }^{7}$ som regelmæssigt praktiserer indsamling af forskellige spiselige plantedele, svampe, bær, frugter, larver, insekter, padder og andet. Indsamlingen tillægges ikke stor betydning af ashéninka selv. At indsamlingen faktisk forsyner ashéninkaerne med livsvigtige vitaminer, er alene antropologens påstand og noget, som ligger helt uden 
fingertykke larver, mawu, eller der hentes termitter ud af deres bo eller indsamles snegle, paddeyngel og andet spiseligt. Derudover indsamles blandt andet bestemte typer lianer, bark og forskellige græsarter, som anvendes til fremstilling af kurve, måtter, vifter, reb og snor, ligesom der samles harpiks til optænding og som bindemiddel, palmeblade til tagdækning og palmebark til vægbeklædning og gulve eller bestemte typer bark og frugter til farvning af tekstiler. Fællesudflugter, hvor både mænd og kvinder deltager, kan have til formål at grave bæltedyr op af de huler under jorden, hvor de holder til. De kan også være fiske-ture, hvor mændene medbringer rødder af barbasco, som de banker ud i vandet. Dette bevirker, at fiskene lammes og flyder til overfladen, hvor kvinder og børn slet og ret samler dem ind i deres kurve. Større fisk, hvis sådanne findes, som kun påvirkes let af giften, vil mændene harpunere eller skyde med bue og pil.

Da forekomsten af fisk i de floder, som gennemkrydser Gran Pajonal, imidlertid er meget begrænset, er der ikke tale om et egentligt fiskeri. Her er mere præcist tale om en form for indsamling rettet mod alle arter af smådyr, som findes i vand, og som omfatter alt spiseligt fra fiskeyngel, frøæg og guldsmedelarver over haletudser til snegle og andet spiseligt småkryb. Det er ikke helt forkert at sige, som John Bodley gør det, at Pajonal-ashéninka spiser alt, hvad der bevæger sig (Bodley 1971:34). Dette er en nødvendighed for at kunne overleve i et område som Gran Pajonal, hvor forekomsten af større vildt er ringe. Denne nødvendighed fratager imidlertid ikke indsamlingen dens umiddelbare karakter af fornøjelsestur eller eventuelt „nødløsning“: I ashéninkas eget perspektiv er indsamling nemlig ikke seriøst arbejde, men noget man gør af lyst eller som en nødforanstaltning. Indsamlingsekspeditioner bruges desuden som påskud til at komme bort fra bopladsen og fra den sociale overvågning, som livet på en boplads indebærer. Unge forelskede par går således i skoven alene sammen eller blot i følge med deres børn på undertiden flere dage lange ,indsamlingsture“, hvor de får ro til at dyrke hinandens selskab i fred for slægt og venners utidige indblanding. Tilsvarende kan indsamlingsture bruges til midlertidigt at søge bort, når der er optræk til konflikter på en boplads. Ud over disse åbenbare sociale funktioner yder indsamlingen et kritisk bidrag til ashéninkas ernæring, hvilket formentlig er baggrunden for, at indsamling på trods af sin status som ,ikke-arbejde“ er en aktivitet, som sker fortløbende og med en ekspertise, der vedblivende overføres mellem generationerne.

\section{Indsamling og ernæring}

Ashéninkas kendskab til skovens planter, dyr og insekter er overvældende. Selv om indsamlingen i skoven for en flygtig betragtning tager sig ud som adspredelse mere end egentlig nødvendig produktion, bliver det klart, når man ser nærmere efter ud fra et ernæringsmæssigt synspunkt, at de indsamlede produkter er helt centrale for ashéninkas opretholdelse af en god ernæringstilstand. Dette er ikke et ukendt fænomen blandt interfluviale Amazonbefolkninger, om end man har været tilbøjelig til at undervurdere indsamlingens betydning for grupper, som ikke er jæger-samlere, men netop som ashéninka er svedjebrugere med jagt/fiskeri/indsamling som supplerende næringsstrategi.

Nyere studier i troperne har vist, at et stort indtag af insekter og hvirvelløse dyr bidrager signifikant til befolkningernes ernæring, idet denne type fødemidler indeholder et væsentligt tilskud af højkvalitetsproteiner (Little 1985:xx). Ifølge målinger af næ- 
steder næsten dagligt, gør det. Det er almindeligt, at kvinder og børn fra en boplads drager i skoven to eller flere sammen for at finde for eksempel larver, termitter, myrer, honning, snegle, frøer, haletudser, palmefrugter, nødder, bær, svampe eller palmemarv. En sådan udflugt gøres gerne til en fornøjelsestur, hvor man spiser og holder pauser under udfoldelse af megen snak og morskab, mens skovens bund afsøges for tommel- 
